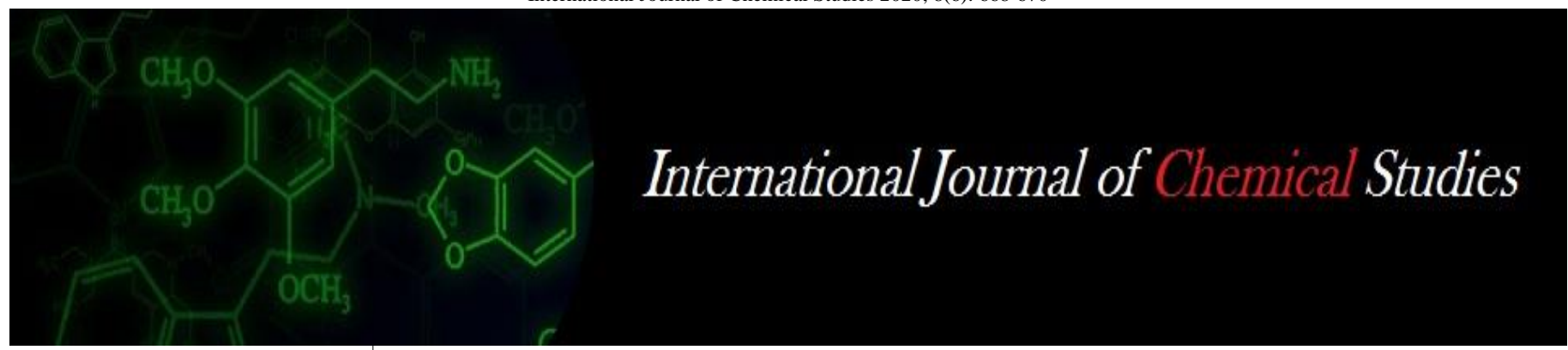

P-ISSN: 2349-8528

E-ISSN: 2321-4902

www.chemijournal.com

IJCS 2020; 8(6): 668-670

(C) 2020 IJCS

Received: 08-08-2020

Accepted: 18-09-2020

\section{Roshan Varadkar}

Department of Horticulture,

College of Horticulture, Dapoli,

Dr. Balasaheb Sawant Konkan

Krishi Vidyapeeth, Dapoli,

Ratnagiri, Maharashtra, India

BR Salvi

Department of Horticulture,

College of Horticulture, Dapoli,

Dr. Balasaheb Sawant Konkan

Krishi Vidyapeeth, Dapoli,

Ratnagiri, Maharashtra, India

\section{Kulkarni}

Department of Horticulture, College of Horticulture, Dapoli, Dr. Balasaheb Sawant Konkan Krishi Vidyapeeth, Dapoli,

Ratnagiri, Maharashtra, India

PC Haldavnekar

Department of Horticulture, College of Horticulture, Mulde, Dr. Balasaheb Sawant Konkan Krishi Vidyapeeth, Dapoli, Ratnagiri, Maharashtra, India

Corresponding Author: Roshan Varadkar Department of Horticulture, College of Horticulture, Dapoli, Dr. Balasaheb Sawant Konkan Krishi Vidyapeeth, Dapoli, Ratnagiri, Maharashtra, India

\section{Effect of potting media on per cent germination and growth of Jackfruit (Artocarpus heterophyllus L.) grafts cv. Konkan prolific}

\author{
Roshan Varadkar, BR Salvi, MM Kulkarni and PC Haldavnekar
}

DOI: https://doi.org/10.22271/chemi.2020.v8.i6j.10846

\begin{abstract}
Among the tropical fruits, Jackfruit (Artocarpus heterophyllus L.) is an important underutilized fruit and often called the poor man's fruit because of its affordability and availability in large quantities during the season. The jackfruit trees are raised by seeds and therefore the progenies do not breed true to type and show many variations. Hence, vegetative propagation methods are must in jackfruit. For this standardization of its germination of seedlings and vegetative propagation techniques plays an important role. Hence, experiment proposed entitled "Effect of potting media on per cent germination and growth of Jackfruit (Artocarpus heterophyllus L.) grafts cv. Konkan Prolific" was conducted at Fruit Crop Nursery of Department of Horticulture, Dr. Balasaheb Sawant Konkan Krishi Vidyapeeth, Dapoli during 2012-2013. In this experiment eight potting media were tried in Randomized Block Design and replicated at thrice. Among the different potting media Soil + FYM (1:1) media gave higher seed germination, seedling growth and vigour up to 30 days.
\end{abstract}

Keywords: Potting media, germination, jackfruit grafts and Konkan prolific

\section{Introduction}

Jackfruit, Artocarpus heterophyllus L. belonging to family Moraceae is one of the most popular and widely grown, evergreen fruit tree. Jackfruit produces heavier yields than any other tree species and bears largest known edible fruit weighing around $35-50 \mathrm{~kg}$ each. This is one of the underexploited nutritious fruit crop indigenous to the rainforests of Western Ghats of India (Reddy et al., 2004) ${ }^{[9]}$. The full commercial exploitation of these existing jackfruit plants has not been possible because of their heterozygous in nature. There is a wide variation with respect to fruit size, shape, quality, season of bearing and harvesting. The jackfruit trees are raised by seeds and therefore the progenies do not breed true to type and show many variations. The success of nursery is largely depends on healthy rootstock for grafting. Potting media plays an important role in seed germination. Media not only acts as a growing place but also good source of nutrient for plant growth (Ramteke et al., 2015) ${ }^{[8]}$. Hence, it is of prime importance to standardize the suitable potting media for commercial production of jackfruit seedling for grafting.

\section{Material and Methods}

The experiment was conducted at Fruit Crop Nursery, Department of Horticulture, College of Agriculture Dapoli, Dist. Ratnagiri during the year 2012-2013 with different potting media viz., $\mathrm{T}_{1}-$ Soil + FYM (1:1), $\mathrm{T}_{2^{-}}$Soil + FYM (2:1), $\mathrm{T}_{3}-$ Soil + FYM (3:1), $\mathrm{T}_{4}-$ Soil + Vermicompost (1:1), $\mathrm{T}_{5}$ - Soil + Vermicompost (2:1), $\mathrm{T}_{6}$ - Soil + Vermicompost (3:1), $\mathrm{T}_{7}-$ Soil + Sand + FYM (1:1:1) and $\mathrm{T}_{8^{-}}$Soil + Sand + Vermicompost (1:1:1). Uniform sized, fully ripe fruits were selected. The seeds were extracted, washed with clean water and dried in shade for a day. The soaking of seeds carried out for 24 hours in clean water before sowing. The different combinations of soil, sand, FYM and vermicompost as per the treatment combinations were used for filling the polythene bags of $15 \times 20 \mathrm{~cm}$ in size. Seeds of jackfruit were sown in individual polythene bags up to the depth of 2-2.5 cm. Per cent seed germination at fifteen and thirty days after sowing, were recorded. Germination percentage were calculated by dividing the total number of germinated seeds by the total number of seeds sown and 
multiplied by 100 . Observations on growth of five grafts randomly selected in each treatment were recorded at 15 days and 30 days after grafting viz., Plant height $(\mathrm{cm})$, Girth at collar region $(\mathrm{cm})$, Number of leaves and Dry matter (g.). The dry matter (g) was estimated at one month old jackfruit grafts. The uprooted grafts were filled in separate brown paper bag and kept in hot air oven. Weighing was done regularly until they attain constant weight. This constant weight was recorded as dry matter. The data in the present investigation was statistically analyzed by the method suggested by Panse and Sukhatme (1985) ${ }^{[7]}$.

\section{Result and Discussions}

Effect of potting media on germination percentage of jackfruit: Data pertaining to the effect of potting media on per cent seed germination of jackfruit are presented in table 1. At 15 days after sowing, per cent seed germination was significantly varied from 24.67 to 46.00 per cent among all potting media treatments. Significantly the highest $(46.00 \%)$ seed germination was observed in treatment $T_{7}$ which was at par with treatment $\mathrm{T}_{1}, \mathrm{~T}_{2}, \mathrm{~T}_{3}, \mathrm{~T}_{4}$ and $\mathrm{T}_{8}$. Significantly lowest $(24.67 \%)$ seed germination was observed in treatment $T_{5}$. Similarly, at 30 days after sowing, per cent seed germination was significantly varied from 71.00 to 90.00 per cent, among all potting media treatments. Significantly the highest $(90.00 \%)$ seed germination was observed in treatment $\mathrm{T}_{7}$ and it was at par with $\mathrm{T}_{1}, \mathrm{~T}_{2}, \mathrm{~T}_{3}, \mathrm{~T}_{4}$ and $\mathrm{T}_{8}$. Significantly lowest $(71.00 \%)$ seed germination was observed in treatment $T_{5}$. However, the present findings are confirmative with results reported by Hande (1987) ${ }^{[4]}$ in Jamun and Gawankar et al., (2019) [3] in jackfruit seed germination in various potting media.

Effect of potting media on plant height $(\mathrm{cm})$ of jackfruit grafts cv. Konkan Prolific: The data on the growth of jackfruit grafts raised in different media are presented in table 2 . At 15 days after grafting, height of jackfruit grafts was nonsignificantly varied from 18.38 to $20.96 \mathrm{~cm}$ among all the potting media. Data present in Table 2 revealed that at 30 days after grafting, height of jackfruit grafts was significantly varied from 20.12 to $22.81 \mathrm{~cm}$ among all the potting media. Significantly highest $(22.81 \mathrm{~cm})$ graft height was observed in $\mathrm{T}_{2}$ treatment which was at par with treatments $\mathrm{T}_{1}, \mathrm{~T}_{6}, \mathrm{~T}_{7}$ and $\mathrm{T}_{8}$. However, the lowest $(20.12 \mathrm{~cm})$ graft height was observed in treatment $\mathrm{T}_{4}$. The similar findings were accordance with Gawankar et al., (2019) ${ }^{[3]}$ in jackfruit.

Effect of potting media on girth at collar region $(\mathrm{cm})$ of jackfruit grafts cv. Konkan Prolific: Data present in table 2 showed that, at 15 days after grafting, girth at collar region of jackfruit grafts was non-significantly varied from 1.07 to 1.27 $\mathrm{cm}$ among all the potting media. Similarly, at 30 days after grafting, girth at collar region of jackfruit grafts was nonsignificantly varied from 1.17 to $1.34 \mathrm{~cm}$ among all the potting media.
Effect of potting media on number of leaves of jackfruit grafts cv. Konkan Prolific: The data pertaining to number of leaves per plant due to allotted treatments at various growth stages are presented in table 2. Data showed that, at 15 days after grafting, numbers of leaves of jackfruit grafts were nonsignificantly varied from 1.30 to 2.40 among all the potting media. Similarly, at 30 days after grafting, numbers of leaves of jackfruit grafts were non significantly varied from 2.13 to 3.53 among all the potting media.

Effect of potting media on dry matter (g) of jackfruit grafts cv. Konkan Prolific: The overall functioning of plant ultimately leads to the formation and progressive accumulation of the dry matter in the plant body. Thus, the growth of plant is nothing but the progressive accumulation of dry matter. The data regarding the dry matter production as affected by potting media are presented under table 2 . At 30 days after grafting, dry matter of jackfruit grafts was significantly varied from 2.10 to $4.00 \mathrm{~g}$. Among all the potting media treatments. Significantly highest $(4.00 \mathrm{~g})$ dry matter was observed in treatment $T_{1}$. Whereas, lowest $(2.10 \mathrm{~g})$ dry matter was noted in treatment $\mathrm{T}_{7}$. Potting media treatments showing dry matter $(\mathrm{g})$ of jackfruit grafts in descending order is as $\mathrm{T}_{1}>\mathrm{T}_{2}>\mathrm{T}_{3}>\mathrm{T}_{4}>\mathrm{T}_{6}>\mathrm{T}_{5}>\mathrm{T}_{8}>\mathrm{T}_{7}$. The results are confirmative with Das et al., (2006) ${ }^{[1]}$ in sapota air grafts, Iftikhar and Qasim (2003) ${ }^{[5]}$, Firoz et al., (1998) ${ }^{[2]}$ in cherry cuttings, and Nagwekar (1981) ${ }^{[6]}$ in mango grafts.

Table 1: Effect of potting media on per cent seed germination of jackfruit.

\begin{tabular}{|c|c|c|}
\hline \multirow{2}{*}{ Treatments } & \multicolumn{2}{|c|}{ Per cent seed germination } \\
\cline { 2 - 3 } & 15 Days After Sowing & 30 Days After Sowing \\
\hline \multirow{2}{*}{$\mathrm{T}_{1}$} & 38.00 & 84.00 \\
& $(38.05)$ & $(66.83)$ \\
\hline \multirow{2}{*}{$\mathrm{T}_{2}$} & 32.00 & 76.00 \\
& $(34.31)$ & $(61.41)$ \\
\hline \multirow{2}{*}{$\mathrm{T}_{3}$} & 37.33 & 82.00 \\
& $(37.65)$ & $(64.96)$ \\
\hline \multirow{2}{*}{$\mathrm{T}_{4}$} & 40.67 & 89.00 \\
& $(39.61)$ & $(70.64)$ \\
\hline \multirow{2}{*}{$\mathrm{T}_{5}$} & 24.67 & 71.00 \\
& $(29.51)$ & $(57.44)$ \\
\hline \multirow{2}{*}{$\mathrm{T}_{6}$} & 26.67 & 76.00 \\
& $(31.00)$ & $(60.78)$ \\
\hline \multirow{2}{*}{$\mathrm{T}_{7}$} & 46.00 & 90.00 \\
& $(42.70)$ & $(71.58)$ \\
\hline \multirow{2}{*}{$\mathrm{T}_{8}$} & 33.33 & 79.00 \\
& $(35.15)$ & $(62.73)$ \\
\hline \multirow{2}{*}{ Mean } & 34.83 & 80.87 \\
& $(287.98)$ & $(516.38)$ \\
\hline 'F' test & SIG & SIG \\
\hline SEm \pm & 3.29 & 3.49 \\
\hline C.D. at $5 \%$ & 9.98 & 10.57 \\
\hline
\end{tabular}

(Statistical analysis is based on the transformed values of the per cent germination).

Table 2: Effect of potting media on plant height $(\mathrm{cm})$, Girth at collar region $(\mathrm{cm})$, number of leaves and dry matter $(\mathrm{g})$ of jackfruit grafts $\mathrm{cv}$. Konkan Prolific

\begin{tabular}{|c|c|c|c|c|c|c|c|}
\hline \multirow{2}{*}{ Treatments } & \multicolumn{2}{|c|}{ Plant height (cm) } & \multicolumn{2}{c|}{ Girth (cm) at collar region } & \multicolumn{2}{c|}{ Number of leaves } & Dry matter (g) \\
\cline { 2 - 8 } & $\begin{array}{c}\text { 15 Days After } \\
\text { Grafting }\end{array}$ & $\begin{array}{c}\text { 30 Days After } \\
\text { Grafting }\end{array}$ & $\begin{array}{c}\text { 15 Days After } \\
\text { Grafting }\end{array}$ & $\begin{array}{c}\text { 30 Days After } \\
\text { Grafting }\end{array}$ & $\begin{array}{c}\text { 15 Days After } \\
\text { Grafting }\end{array}$ & $\begin{array}{c}\text { 30 Days After } \\
\text { Grafting }\end{array}$ & $\begin{array}{c}\text { 30 Days After } \\
\text { Grafting }\end{array}$ \\
\hline $\mathrm{T}_{1}$ & 19.83 & 22.33 & 1.27 & 1.34 & 1.40 & 3.53 & 4.00 \\
\hline $\mathrm{T}_{2}$ & 20.96 & 22.81 & 1.19 & 1.28 & 1.50 & 3.07 & 3.47 \\
\hline $\mathrm{T}_{3}$ & 18.38 & 20.52 & 1.10 & 1.21 & 2.30 & 3.13 & 3.10 \\
\hline $\mathrm{T}_{4}$ & 19.13 & 20.12 & 1.19 & 1.31 & 1.30 & 2.33 & 2.90 \\
\hline
\end{tabular}




\begin{tabular}{|c|c|c|c|c|c|c|c|}
\hline $\mathrm{T}_{5}$ & 18.42 & 20.72 & 1.07 & 1.17 & 1.30 & 2.13 & 2.30 \\
\hline $\mathrm{T}_{6}$ & 20.01 & 22.16 & 1.15 & 1.21 & 2.40 & 2.57 & 2.37 \\
\hline $\mathrm{T}_{7}$ & 19.01 & 22.54 & 1.25 & 1.33 & 1.80 & 3.50 \\
\hline $\mathrm{T}_{8}$ & 19.48 & 21.65 & 1.10 & 1.21 & 1.50 & 3.13 & 2.10 \\
\hline Range & $18.38-20.96$ & $20.12-22.81$ & $1.07-1.27$ & $1.17-1.34$ & $1.30-2.40$ & $2.13-3.53$ & $2.10-4.00$ \\
\hline Mean & 19.40 & 21.61 & 1.16 & 1.25 & 1.69 & 2.92 & 2.80 \\
\hline 'F' test & NS & SIG & NS & NS & NS & NS & SIG \\
\hline SEm \pm & 0.65 & 0.39 & 0.06 & 0.07 & 0.37 & 0.44 & 0.02 \\
\hline C.D. at 5\% & & 1.17 & - & & & \\
\hline
\end{tabular}

\section{Treatment details}

\begin{tabular}{|c|c|c|c|}
\hline $\mathrm{T}_{1}$ & Soil + FYM $(1: 1)$ & $\mathrm{T}_{5}$ & Soil + Vermicompost (2:1) \\
\hline $\mathrm{T}_{2}$ & Soil + FYM $(2: 1)$ & $\mathrm{T}_{6}$ & Soil + Vermicompost $(3: 1)$ \\
\hline $\mathrm{T}_{3}$ & Soil + FYM $(3: 1)$ & $\mathrm{T}_{7}$ & Soil + Sand + FYM $(1: 1: 1)$ \\
\hline $\mathrm{T}_{4}$ & Soil + Vermicompost $(1: 1)$ & $\mathrm{T}_{8}$ & Soil + Sand + Vermicompost $(1: 1: 1)$ \\
\hline
\end{tabular}

\section{Conclusion}

Thus, from the present investigation, it could be concluded that, $\mathrm{T}_{1}$ Soil + FYM (1:1) potting media had shown better results in per cent seed germination and all the growth parameters of jackfruit grafts up to 30 days age followed by $\mathrm{T}_{7}$ Soil + Sand + FYM (1:1:1).

\section{References}

1. Das BK, Das JN, Archana GC. Effect of potting media on air-grafting of five sapota varieties. Orissa Journal of Horticulture 2006;34(2):18-22.

2. Firoz ZA, Hossain MM, Choudhury AK, Chowdhury MU. Effect of root growth media and parts of shoot cutting on the success of cherry. Thai Journal of Agricultural Science. 1998;31(1):47-52.

3. Gawankar MS, Haldankar PM, Haldavnekar PC, Salvi BR, Jamadagni BM. Studies on seed germination and seedling growth in Jackfruit (Artocarpus heterophyllus Lam.) as influenced by media. International Journal of Chemical Studies 2019;7(5):1699-1705.

4. Hande RB. Propagation studies of Jamun (Eugenia jambolana L.). A M.Sc. (Agri.) thesis submitted to Dr. B.S.K.K.V., Dapoli, Dist. Ratnagiri, Maharashtra 1987.

5. Iftikhar, Ahmad, Qasim M. Influence of various potting media on growth and nutrient uptake efficiency of Scindapsus aureus. International Journal of Agriculture and Biology 2003;5(4):594-597.

6. Nagwekar DD. Studies on survival and growth of mango (Mangifera indica L.) grafts. A M.Sc. (Agri.) thesis submitted to Dr. B.S.K.K.V., Dapoli, Dist. Ratnagiri, Maharashtra 1981.

7. Panse VG, Sukhatme PV. Statistical methods for agricultural workers $2^{\text {nd }}$ Ed. ICAR, New Delhi 1985, 157165.

8. Ramteke V, Paithankar DH, Ningot EP, Kurrey VK. Effect of $\mathrm{GA}_{3}$ and propagation media on germination, growth and vigour of papya (Carica papaya L.) cv. Coorg Honey Dew. The Bioscan 2015;10(3):1011-1016.

9. Reddy BM, Patil CP, Shashikumar S, Govindaraju LR. Studies on physico-chemical characteristics of jackfruit clones of south Karnataka. Karnataka Journal of Agricultural Sciences 2004;17: 279-2. 